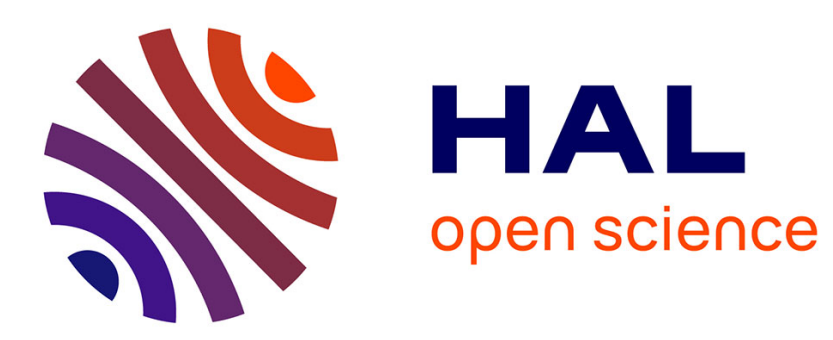

\title{
Youngest Toba Tuff in the Son Valley, India: a weak and discontinuous stratigraphic marker
}

E. Gatti, A.J. Durand, P.L. Gibbard, Clive Oppenheimer

\section{To cite this version:}

E. Gatti, A.J. Durand, P.L. Gibbard, Clive Oppenheimer. Youngest Toba Tuff in the Son Valley, India: a weak and discontinuous stratigraphic marker. Quaternary Science Reviews, 2011, 30 (27-28), pp.3925-3934. 10.1016/j.quascirev.2011.10.008 . insu-00707153

\section{HAL Id: insu-00707153 \\ https://hal-insu.archives-ouvertes.fr/insu-00707153}

Submitted on 11 Jul 2012

HAL is a multi-disciplinary open access archive for the deposit and dissemination of scientific research documents, whether they are published or not. The documents may come from teaching and research institutions in France or abroad, or from public or private research centers.
L'archive ouverte pluridisciplinaire HAL, est destinée au dépôt et à la diffusion de documents scientifiques de niveau recherche, publiés ou non, émanant des établissements d'enseignement et de recherche français ou étrangers, des laboratoires publics ou privés. 


\title{
Youngest Toba Tuff in the Son Valley, India: a weak and discontinuous stratigraphic marker
}

E. Gatti $i^{\mathrm{a}}$

\author{
A.J. Durant $\underline{\mathrm{bcd}}$ \\ P.L. Gibbard ${ }^{\mathrm{a}}$ \\ C. Oppenheimer \\ ${ }^{a}$ Department of Geography, University of Cambridge, Downing Place, CB2 3EN, \\ Cambridge, UK \\ ${ }^{\mathrm{b}}$ Centre for Atmospheric Science, Department of Chemistry, University of Cambridge, \\ Lensfield Road, Cambridge, CB2 1EW, UK \\ ${ }^{c}$ Norwegian Institute for Air Research, P.O. Box 100, NO-2027 Kjeller, Norway \\ ${ }^{\mathrm{d}}$ Geological and Mining Engineering and Sciences, Michigan Technological University, \\ USA \\ ${ }^{\mathrm{e}}$ Le Studium, Institute for Advanced Studies, Orléans and Tours, France \\ ${ }^{\mathrm{f}}$ L'Institut des Sciences de la Terre d'Orléans, l'Université d'Orléans, 1a rue de la \\ Férollerie, 45071 Orléans, cedex 2, France
}

\begin{abstract}
Investigation of the climatic and environmental impacts of the Youngest Toba Tuff (YTT, $\sim 74$ ka BP) eruption of Toba volcano, Sumatra, is crucial for understanding the consequences of the eruption for contemporaneous human populations. The Middle Son Valley, in India, was the first locality on the Indian subcontinent where the YTT was reported. The ash bed forms a discontinuous layer stretching for over $30 \mathrm{~km}$ along the river. Here we report on the stratigraphic contexts of YTT ash layers in alluvial deposits of the Middle Son Valley, in order to reconstruct the taphonomy of the ash deposits and the dynamic of their deposition. Although the distal ash has been studied since the 1980s, its stratigraphic integrity and the mechanisms and pathways involved in its transport and deposition have bit previously been assessed. We find that the YTT occurrences in the Middle Son Valley may not be reliable chronostratigraphical markers for millennial scale palaeoenvironmental reconstruction.
\end{abstract}

\section{Keywords}

Toba; Son Valley; Tephra; Fluvial geomorphology 


\section{Introduction}

The first reported finds of Youngest Toba Tuff (YTT) deposits in India were made in the Middle Son Valley (Madhya Pradesh, North Central India; Williams and Royce, 1982). Initially these sites were investigated for their abundance of Middle Palaeolithic archaeological assemblages (Acharyya and Basu, 1993), but since the 1980s they have become the focus of palaeoenvironmental studies concerned with understanding the immediate and longer term impacts of the YTT super-eruption on climate and human occupation (Basu et al., 1987).

The $\sim 74$ ka YTT super-eruption of the Toba volcano in northern Sumatra (Fig. 1) is the largest eruption known for the Quaternary (Chesner and Rose, 1991). The total mass of rhyolitic magma ejected has been estimated crudely as $7 \times 10^{15} \mathrm{~kg}$ (or $2800 \mathrm{~km}^{3}$ dense rock equivalent, DRE) ( [Rose and Chesner, 1990], [Chesner and Rose, 1991] and [Chesner et al., 1991]). This deposit includes $\sim 1000 \mathrm{~km}^{3}$ (DRE) of co-ignimbrite tephra fallout, which covered $\sim 2 \times 10^{7} \mathrm{~km}^{2}$ of southern and southeast Asia. The tephra deposits are preserved in alluvial settings across India and peninsular Malaysia (e.g. [Ninkovich et al., 1978a], [Ninkovich et al., 1978b] and [Westgate et al., 1998]), and in deep-sea tephra layers in the Indian Ocean, the Bay of Bengal and South China Sea ( [Ninkovich, 1979], [Pattan et al., 1999], [Gasparotto et al., 2000], [Song et al., 2000] and [Schulz et al., 2002]).

The YTT eruption must also have injected substantial quantities of sulphur into the middle atmosphere argued in early works to have induced a 'volcanic winter' (Rampino and Self, 1992). Later studies suggested the climate forcing due to the volcanic aerosol veil might have accelerated the onset of stadial conditions during the 1000 year-interval between DansgaardOeschger events 19 (70-68 ka) and 20 (75-71 ka) (Zielinski et al., 1996) though there is no strong evidence to substantiate this hypothesis. Proponents of extreme change scenarios have concluded that ecosystems and hominid populations were devastated as a result (Ambrose, 1998). However, others have cautioned against assuming extreme global climate impacts given the limited constraints on the sulphur yield of the eruption and on the date of any palaeodemographic 'bottleneck' in anatomically modern human populations (Oppenheimer, 2002), as well as a lack of evidence for population crashes in contemporary fauna ( [Ambrose, 2003] and [Gathorne-Hardy and Harcourt-Smith, 2003]).

To improve understanding of the extent and severity of environmental impacts of the YTT eruption it is critical to determine how long it took for the ash to be redeposit and consolidated in the receiving landscape; the longer the ash remained mobile in the environment, the more chronic the impact on vegetation and associated ecosystems would have been (Jones, 2010). Tephra successions, if suitably preserved, provide chronostratigraphical markers within sedimentary sequence (Sarna-Wojcicki and Davis, 1991). Hydrological systems may also be inundated with sediment following ash fallout which results in rapid accumulation rates and preservation of indicators of sudden remobilisation and re-deposition of unconsolidated pyroclastic material ( [Hayes et al., 2002], [Manville et al., 2005] and [Kataoka et al., 2009]).

The YTT stratum in the Middle Son Valley has been repeatedly used as a marker in geoarchaeological investigations of sediment sequences ( [Williams and Royce, 1982] and [Jones and Pal, 2005]). However, its reliability as a stratigraphical marker has until now not been considered. In this paper, we contextualise the distal YTT stratum of the Middle Son Valley through study of the stratigraphy of the volcaniclastic sequences, and we provide textural and structural details about the ash units. We present a series of stratigraphic sections containing 
YTT tephra located within the modern riverside cliffs. Specifically, we describe the tephra sites between the Rehi River and the site of Khunteli (Fig. 2).

We provide an interpretation of the river activity before and after the eruption, revealing the characteristics of the ash preserved in selected environmental niches. This is the first sedimentological and geomorphological study of the YTT deposits in the Middle Son Valley. The model, together with the field evidence, suggests that the YTT deposits of the Son Valley area do not provide a reliable chronostratigraphical marker in the region for long-term palaeoenvironmental reconstructions and archaeological correlations, except for the site of Ghoghara.

\section{Study area}

The Middle Son Valley is located $100 \mathrm{~km}$ south from Allahabad and $130 \mathrm{~km}$ southwest of Varanasi, in north central India $\left(24^{\circ} 7^{\prime} \mathrm{N} 80^{\circ} / 83^{\circ} 50^{\prime} \mathrm{E}\right.$, Fig. 2). The regional climate is subtropical, characterised by hot humid summers (April-September, temperatures $>40{ }^{\circ} \mathrm{C}$ ), and cooler winters (October-March) with low precipitation. Affected by the summer monsoon from June to September, the topography and geomorphology of the hills and valleys reflect the intense summer runoff, which has deeply incised the river terraces.

The Son (784 km long) is one of the longest rivers of India and the longest of the southern tributaries feeding into the River Ganges. It flows, as does the Narmada River, along the line of a major E-W tectonic lineament, the Narmada fault (Williams and Royce, 1982).

Originating in Madhya Pradesh, just east of the Narmada River, the Son flows northnorthwest and cuts through Middle Proterozoic limestone and shale of the Vindhyan SuperGroup (Singh, 1980) and Middle-Pleistocene and Holocene alluvial plains, before turning eastwards to encounter Middle Proterozoic sandstones of the Kaimur Range (Morad et al., 1991). The modern channel has incised the metamorphic bedrock to a depth of about 30$35 \mathrm{~m}$, forming deposits of fluvial sand (Williams and Royce, 1982). Throughout its history, the passage of the Son river has been strongly influenced by climatic factors (reflected in changes in its floodplain deposition and channel down cutting), since the river is constrained laterally as a consequence of its geological setting (Sharma and Clark, 1982).

The area of study includes the river-cut cliffs in the alluvial zone between the confluence of the Rehi and Son rivers and Khunteli (or Khuteli) (Fig. 2). The reported YTT deposits ( [Acharyya and Basu, 1993] and [Jones and Pal, 2005]) comprise a discontinuous tephra bed covering an area of $\sim 90 \mathrm{~km}^{2}$. Between Rehi and Ghoghara (first described by Williams and Royce in 1982), lateral variations within the ash deposits are minimal, and the ash layer appears repeatedly at a height between 4 and $6 \mathrm{~m}$ above the present river bed (Fig. 3).

The Son River alluvial basin includes terraced surfaces flanked by floodplains, point-bar and alluvial fan deposits. The main river channel is bounded by a series of Middle and Late-

Pleistocene and Early-Holocene sedimentary terraces that reach altitudes of as much as $30 \mathrm{~m}$, and deeply-incised seasonal channels known as 'nalas'. The terrace, incised by the modern Son River, has been intensively studied due to the presence of the YTT marker and the coincidence of archaeological sites, where Middle Palaeolithic and Neolithic artefacts have been found ( [Sharma and Clark, 1982], [Williams and Royce, 1982], [Williams and Royce, 1983], [Jones and Pal, 2005], [Jones and Pal, 2009] and [Haslam et al., 2010]). 
Four formations have been historically ascribed to the alluvial deposits of the Son Valley. In chronological order they are: Sihawal Formation, Patpara Formation, Baghor Formation and Khetaunhi Formation ( [Williams and Royce, 1982], [Williams and Royce, 1983], [Williams and Clarke, 1995] and [Williams et al., 2006]). The geological context of the incised terrace is unclear, mainly due to the absence of absolute dates and robust stratigraphic correlation (Jones and Pal, 2009).

Several models have been proposed for the geomorphological evolution of the alluvial plain of the Middle Son Valley through the period Early Pleistocene to Late Holocene ( [Williams and Royce, 1982], [Williams and Royce, 1983], [Williams and Clarke, 1995] and [Williams et al., 2006]). These authors analysed the large-scale evolution of the river based on differences between the four formations and distinct climatic regimes. A stratigraphical model (at $1 \mathrm{~km}$ scale) of the emplacement of all the four formations within the river basin was also proposed by Williams and Clarke (1995) and modified by Williams et al. (2006).

\section{Methodology and site selection}

For this work we aimed to assess the validity of the tephra as stratigraphic marker. In an attempt to correlate the tephra layer across sections we surveyed a $30 \mathrm{~km}$ length along the river banks, logged and sampled specific sites. Serial photographs of cliff sections were taken from boat and bank traverses, and photomosaics were constructed to aid contextualisation of the YTT layer in the stratigraphy. Modern topography was characterised using a Total Station (Zeiss Elta R55 EDM). The 600 points grid obtained was interpolated using the programmes Surfer 3.0 and ArcMap (Fig. 3) providing a further means of investigating the distribution of tephra.

We describe here six tephra type- sections, out of the nine discovered and surveyed during the 2009 field work (Table 1). Two of these sites, GG1 and KH, have been previously described in the literature ( [Williams and Royce, 1982], [Jones and Pal, 2005], [Jones and Pal, 2009], [Williams et al., 2006] and [Jones, 2010]). The six sites were selected on the basis of their ash characteristics (Par. 2.1.), sedimentological structures and spatial distribution.

In order to isolate the depositional environments in which the tephra were identified, the sediments have been assigned facies and floodplain associations using the codes proposed by Miall (1996) and Nanson and Croke (1992), respectively. We identified the major facies assemblages and the depositional settings prevailing at the time of the ash deposition. This leads us to propose a geomorphological model for the dynamic activity of the river through the critical period of interest.

\subsection{Criteria for discriminating primary ash fallout and reworked tephra deposits}

For this work, we selected sites representing primary and/or reworked ash, and considered textural, sedimentological and stratigraphic characteristics of the ash and its associated sediments. Primary (non-reworked) ash-fall is characterised by its: i) colourist whiteness (Munsell code 7.5 YR or 10 YR 8/1 or 8/2); ii) thickness ranging 4-5 cm; iii) sharp lower contact with siliciclastic sediments; iv) homogeneous texture. Secondary (reworked) ash deposits are characterised by: i) post-deposition structures (cross-bedding, root casts, bioturbation); ii) discontinuous/mixed contacts with units above/below; iii) geomorphological features indicating displaced facies (including, blocks of ash within older sediments, traces of slumping, etc.). 


\section{Tephrostratigraphy}

Six sections exposing volcaniclastic deposits were logged and their sedimentological structures described in terms of facies. The resulting logs reveal seven different facies (Table 2).

\subsection{Primary and secondary ash sites}

This section deals with units that include both primary and secondary ash. The sites are located within an area between the Rehi-Son confluence and the cliff on the northern bank of the Son, in the vicinity of the Ghoghara temple (Fig. 2).

Excavations demonstrated that the sites in which primary ash was identified all present a similar stratigraphic context (Fig. 4). The sections include $2-8 \mathrm{~m}$ of cross-bedded brownish medium sand (Facies Scp) and a $5 \mathrm{~cm}$ clay layer (Facies $C l$ ) at the base of the sections and 1$3 \mathrm{~m}$ of micaceous coarse silt (Facies Smc) enriched in calcrete on the top of the sequence, capped with soil (Facies $P$ ) (Fig. 4). The ash horizon can be distinguished within all the studied sections, but only three provide important tephrostratigraphic markers: section RH1, GG1 and GG4. These horizons consist of a $2-8 \mathrm{~cm}$ thick stratum of primary ash (Facies PA) always in sharp contact with the underlying clay, and 1-2 m thick unit of reworked ash (Facies $S A$ ), gradationally overlying Facies $P A$. The primary ash is characterised by powdery, finer grains and whiteness (10YR or 7.5 YR 8/1 and 8/2). The secondary ash is texturally coarser, darker (10 YR 8/3 or 7/1), and appears in massive beds with no apparent depositional structures. The ash sequence gradually coarsens upwards and the contact between the secondary ash and the siliciclastic silt is indistinguishable.

\subsection{Sites showing only reworked ash}

The two sequences with reworked ash show only particular stratigraphic characteristics.

RH2 section (Fig. 5a) is composed of dark brown carbonate cemented clay (Facies Cm); lenses of gravel, in which an admixture of fine sand is also observed within the clay, the latter becoming coarser and carbonate-rich towards the top (Facies Csc and P). The reworked ash $(\sim 1.3 \mathrm{~m}$ thick) is intermixed with the same micaceous silt that overlies the other sequences (Facies Smc). The Munsell colour of the secondary ash of RH2 is 7.5YR 7/4 (pink).

Compared to the primary and secondary sequence, it appears RH2 has only the final part of the volcaniclastic reworked units. Again no sedimentary structures are recognized within the ash unit.

$\mathrm{KH}$ (Fig. 5b) is stratigraphically similar to section GG1, as it exposes the same cross-bedded sand seen at the base of the section ( $\sim 8 \mathrm{~m}$ thick). The cross-bedded sand alternates with fine bands of clayey silt, $2-3 \mathrm{~cm}$ thick: $11 \mathrm{~m}$ above the river bed, the cross-bedded medium sand unit is capped by a fine stratified sand unit and a thick carbonated band. A thin ash layer overlies the latter, 1-cm thick and mixed with clay. The secondary ash unit of KH appears sedimentologically similar to a 2-m lens of volcaniclastic material mixed with clay and laminated sand. The unit is yellowish brown (10 YR 5/4). Although fine laminations appear within the lower sand units and the clay, their origin is uncertain. 


\subsection{Tephra sedimentological structures and geometry}

Much of the tephra deposits in the Son Valley present no evidence of sedimentological structures in the upper reworked tephra layers. The exception is site GG1.b, located in a gully nearby the Ghoghara main section. The site (Fig. 6) presents $\sim 8 \mathrm{~cm}$ basal ash, revealing a "primary" ash layer that itself may be subdivided into the lowermost ash (ash 1), in direct contact with the clay unit; it is $1.5 \mathrm{~cm}$ thick, white (7.5YR 8/1), powdery; on the top, divided by a sharp darker contact, $2.5 \mathrm{~cm}$ of darker ash (ash 2), 7.5YR 8/2, pinkish white; on the top of ash 2, $\sim 8 \mathrm{~cm}$ from the bottom, a $1 \mathrm{~cm}$ thick lens of darker ash, including medium sand grains impurities, is evidenced (ash 3). On the top of ash $3, \sim 3 \mathrm{~cm}$ of white (5YR 8/1) powdery ash (ash 4), visually very similar to ash 2 . Ash 4 is overlain by a heavily bioturbated palaeosurface, ca. $1 \mathrm{~mm}$ thick. The palaeosurface is in sharp contact with a $1.5 \mathrm{~m}$ thick sequence of reworked ash deposits. The unit is characterised by several sedimentary structures (Fig. 6): 1-2 mm thick ripple-like laminations, grouped in cm-thick bands, repeated cyclically every $10 \mathrm{~cm}$; light-dark wavy bands, $1-3 \mathrm{~mm}$ thick, and thicker parallel bands. The volcaniclastic component gradually decreases towards the top of the sequence. No traces of post-depositional disturbance (i.e. slumped blocks, roots, rhyzoliths, carbonate nodules), are found within the ash sequence.

\section{Discussion}

Although the ash of sites GG1 and KH have been explored since the 1980s to elucidate the Quaternary geology and prehistoric environment in the Son Valley, examination of the taphonomy of the ash units has been minimal ( [Jones and Pal, 2009] and [Williams et al., 2006] and 2009). To date, the ash of GG1 was described as "well preserved" and "80 cm relatively pure" (Jones and Pal, 2005), "compact" (Jones, 2010), "discontinuous bed of pure volcanic ash up to $1.5 \mathrm{~m}$ thick" (Williams et al., 2006), "laterally discontinuous unit of volcanic ash up to $4 \mathrm{~m}$ thick" (Williams and Royce, 1983). The reworked ash received less attention, being described only by Williams et al. (2009) as "completely cemented with carbonate from 3.45 to $3.83 \mathrm{~cm}$ above the base of the ash" in the Ghoghara section and "The upper $70 \mathrm{~cm}$ of the ash is reworked" in Khunteli (Williams et al., 2009).

We will discuss the stratigraphical characteristics of YTT sites contextualised in their depositional environment, demonstrating how ash facies associations can unravelled the dynamics of a river depositing, redepositing and preserving the tephra. These features should be considered carefully since using a tephra layer as chronostratigraphical marker.

\subsection{The local environment pre- and post-deposition of the YTT in the middle Son Valley}

The lithofacies assemblages identified represent specific styles and sub-environments of deposition within the catchment. Fig. 7 illustrates the stratigraphical units of the six typesections, the corresponding facies and their lithofacies association.

The sedimentary structures within this facies (cross-lamination, imbrication, poor sorting) indicate that the sand was deposited on a point-bar or counterpoint-bar (cfr. Miall, 1996). The medium grain-size, cross-bedded sand observed at all the sites at the base of the succession (except RH2 and GG1.b), suggests proximity to the active channel. These characteristics indicate a large-scale depositional environment of lateral accretion from the main river channel. The river eroded on one side of the channel and deposited its finer sediments on the other side, creating point-bars and shallow-water deposits. Facies $\mathrm{Cl}$ is suggestive of a distal, 
shallow-water, low-energy environment. This is consistent with the presence of very fine, powdery volcanic ash on the top of this clay. Both Facies $P A$ and $S A$ also suggest a low energy aqueous environment, favourable for preservation of the deposits. The facies association characteristics suggest an overbank environment, established prior to ash deposition. Facies $S m c$ and $P$ are characterised by coarser silt, and pervasive pedogenic features and carbonate nodules. The presence of carbonate nodules and roots clearly indicates a cessation of fluvial activity, and the facies association may represent an abandoned terrace surface, or distal deposits that the river was unable to reach even during floods events.

These multi-facies associations indicate a fluvial floodplain setting consisting of ephemeral ponds and oxbow lakes isolated from the main channel through point-bars and floodplain surfaces, where the ash could be preserved. This is in accordance with microanalyses of the tephra units of Ghoghara and Khunteli by Jones (2010), which highlighted a sensible difference between the particle size distribution of the primary ash $(\sim 60 \mu \mathrm{m})$ and the upper secondary ash layer $(>125 \mu \mathrm{m})$, thus suggesting the primary ash deposited into an aqueous environment.

Fig. 8 shows the lateral accretion and deposition on the point-bar of coarse sediments (gravelsize), the deposition of medium sediments in the near-channel overbank environment (medium and fine sand-size), and accumulation of fine sediments in the distal overbank areas (silt and clay).

As a result of its lateral accretion-aggradation style in this area, the river deposits its sediments laterally and not vertically (Fig. 8a, note the arrow indicating the preferential aggradation direction). In such a setting, following the eruption, primary ash would have been preserved only in protected low-energy niches that were rapidly buried by later sediments. The remaining ash, especially if left exposed at the surface, would have been rapidly eroded to be re-deposited downstream or in lateral channels. The progression from lateral accretion to overbank to abandoned terrace environments apparent in the Ghoghara section suggests a gradual shift in the river morphology. This change in depositional style is reflected in changes in grain size of the deposits (from medium sand to silt) that are typical of fining-upward fluvial sequences: the river fills the channel and its active bed laterally shifted further south.

\subsection{YTT deposits in the middle Son Valley as a chronostratigraphical marker?}

Several attempts have been made to place the YTT within the broader alluvial stratigraphy of the Son Valley, in order to reconcile the history of the alluvial plain with the archaeological artefacts. After reviewing the literature, the exact stratigraphic position of the YTT bed in relation to the Quaternary Formations is unclear. The YTT has been placed within the Baghor Coarse Member ( [Williams and Royce, 1982], [Basu et al., 1987] and [Acharyya and Basu, 1993]), beneath the Baghor Coarse Member (Williams and Clarke, 1995), at the junction between the Patpara Formation and in the Baghor Coarse Member ( [Jones and Pal, 2005] and [Jones, 2010]). More recently it has been proposed that the tephra lies between a newly described Khunteli Formation, dated to 73 ka, and the Patpara Formation, with an age of $56 \mathrm{ka}$ assigned to the latter (Williams et al., 2006).

Here we suggest that these inconsistencies are related to the assumption that the tephra always occurs in its correct stratigraphical position and the lack of dates in direct association with the tephra sediments. Furthermore, the geomorphological model indicates that river aggradation 
has tended to create a lateral discontinuity that disturbs the vertical accumulation, therefore assigning the ash to a specific vertical unit could be misleading.

\subsection{Reliability of the YTT as palaeoenvironmental marker}

A more recent study (Williams et al., 2009) also focused on the Rehi and Khunteli sections, in an attempt to gain insights into the environmental impacts of the YTT eruption. In this work, carbon and oxygen isotopic ratios were measured in calcareous nodules and root casts found below, within and above the ash taken from the GG1 and KH sites. The results suggested replacement of $\mathrm{C}_{3}$ forest that had thrived prior to the YTT fallout by $\mathrm{C}_{4}$-dominated grasslands or wooded grasslands. They concluded that the YTT eruption led to these changes. Similarly Jones (2010) considered the silt-dominated facies overlying the ash a sign of abrupt climatic change immediately after the eruption.

While we are aware that the time-frame and pace of aggradation of the post-tephra units, together with the time of restabilisation of the system, cannot be constrained using stratigraphy only, we also note that there are no evidences that the units above the ash have been deposited immediately after the eruption. The model proposed here implies that the river deposits at Ghoghara and Khunteli were exposed to erosion and reworking, such that the stratigraphy of the ash deposits could result from incision, lateral erosion and redeposition on a timescale of weeks to decades to centuries to millennia. The silt-dominated facies overlying the ash is widespread on the top of all the Middle, Late-Pleistocene and Early Holocene terraces. The post-Toba silt could indicate either that the dynamics of the river channel changed substantially following the eruption (suggesting a strong post-Toba environmental and climatic effect), or that the coarse/medium sand above the ash layer is no longer preserved. The latter could indicate instead a migrating channel and change in facies, suggesting a major geomorphological control on the river rather than eruption-related climatic changes.

The major issue in tackling the palaeoenvironmental impact of the Toba super-eruption is that existing methods of palaeoenvironmental reconstructions lack the analytical precision needed to answer this timescale issue (Williams, in press), and the sedimentation rate in fluvial environments lacks the temporal resolution needed to address questions regarding climate change after the YTT eruption. We consider that the Ghoghara site GG1.b, which fine stratification indicates slow sedimentation conditions, the one locality suitable for chronology-critical work.

\subsection{Reliability of the YTT as an archaeological marker}

Archaeological studies ( [Jones and Pal, 2005], [Jones and Pal, 2009] and [Jones, 2007]) attempted to establish an associations between the ash and the Palaeolithic artefacts in the Middle Son Valley. Using artefacts in secondary contexts Jones and Pal (2009) observed a change in lithic technology and proposed a shift in hominids behaviour during the Upper Pleistocene, suggesting that the Toba eruption may have further contributed to behavioural changes.

We note artefacts have not been recovered from stratigraphic units that show clear evidence of YTT primary ash and the time at which evidence for human populations reappeared may be of the order of millennia (based on the uncertainty of the dating methodologies previously employed, see Jones and Pal, 2009). We have demonstrated the evidence for reworking at 
many of the Middle Son Valley sites, suggesting that the chronological relationship between the artefacts and the YTT strata in the Son Valley is insufficient to allow a robust connection between the eruption and its human impact. The palaeogeomorphology of the area suggests that new archaeological sites in association with primary YTT horizons might be found closer to the interior of the fluvial plain, towards the Rehi River.

\section{Conclusions}

The lithofacies associations revealed from the Rehi-Ghoghara-Khunteli sites indicate an environment conducive to the preservation of primary ash fallout. Nevertheless, the YTT was preserved only in selected geomorphic environments that offered protection to the unconsolidated volcanic particles. This environment was a low energy, shallow-water depression. Before the YTT fallout, the Son River had adopted the characteristics of a sanddominated, medium-sinuosity and low-gradient river, with laterally stable single channel, seasonal floods, floodplains and point-bars. The fining-upwards sequence (reflected in the shift from lateral accretion to overbank and distal channel) could represent the gradual filling of the river bed due to meander migration.

The stratigraphic context of ash deposits in the Middle Son Valley is rarely of the quality required to provide a well-defined chronostratigraphic marker horizon. The ash units are challenging to distinguish from the overlying silts and often show abundant evidence of reworking; the upper boundary is gradational and the reworked units may be several metres thick compared to an initial thickness of 4-5 cm. Most importantly the lower boundary of the ash layer needs to be sharp and undisturbed to provide a clear marker; it was rare to find this condition intact: out of $30 \mathrm{~km}$ of river bank surveyed (on either side of the river) we found only one localised occurrence where the ash could be considered "primary" in context, and neither of the ash locations corresponded to collocation of archaeological artefact assemblages.

It is therefore critical that any future sampling for dating and palaeoenvironmental reconstructions should take full account of the sedimentation style and morphology of the river and the associated evolution of the local landscape through the period.

\section{Acknowledgments}

E.G. thanks the Dudley Stamp Memorial Award, the Cambridge-India Partnership, the SMUTS Memorial Fund and the Philip Lake Fund (Department of Geography, University of Cambridge) for the fieldwork grants. Additional support was provided by the Leverhulme Trust. Jinu Koshy, Janardhana Bora and Hardindra Prasad Ram provided invaluable assistance in the field. We also acknowledge the kindness and hospitality we received in several villages in the Son Valley. We thank J.N. Pal, R. Korisettar, M. Petraglia and M. Haslam for their support of fieldwork in India in 2009, and C. Shipton, C. Clarkson, J. Blinkhorn and S. Jones for discussions on the archaeology of the Son Valley. We thank S. Boreham and C. Rolfe for assistance with the facilities of the Geography Science Laboratories at the Department of Geography, University of Cambridge. Thoughtful reviews from Prof. Williams and Dr. May were greatly appreciated and improved the quality of the manuscript. 


\section{References}

1.

- Acharyya and Basu, 1993

- S.K. Acharyya, P.K. Basu

- Toba ash on the Indian subcontinent and its implications for correlation of late Pleistocene Alluvium

2.

- Ambrose, 1998

- S.H. Ambrose

- Late Pleistocene human population bottlenecks, volcanic winter, and differentiation of modern humans

○ Journal of Human Evolution, 34 (1998), pp. 623-651

3.

- Ambrose, 2003

- S.H. Ambrose

- Did the super-eruption of Toba cause a human population bottleneck? Reply to Gathorne-Hardy and Harcourt-Smith

4.

- Basu et al., 1987

- P.K. Basu, S. Biswas, S.K. Acharyya

- Late Quaternary ash beds from Son and Narmada basins, Madhya Pradesh

○ Indian Minerals, 41 (1987), pp. 66-72

5.

- Chesner and Rose, 1991

- C.A. Chesner, W.I. Rose

- Stratigraphy of the Toba-Tuffs and the evolution of the Toba-Caldera complex, Sumatra, Indonesia

○ Bulletin of Volcanology, 53 (1991), pp. 343-356

6.

- Chesner et al., 1991

- C.A. Chesner, W.I. Rose, A. Deino, R. Drake, J.A. Westgate

- Eruptive history of Earth's largest Quaternary caldera (Toba, Indonesia) clarified

7.

- Gasparotto et al., 2000

- G. Gasparotto, E. Spadafora, V. Summa, F. Tateo

- Contribution of grain size and compositional data from the Bengal Fan sediment to the understanding of Toba volcanic event

- Marine Geology, 162 (2000), pp. 561-572

8.

- Gathorne-Hardy and Harcourt-Smith, 2003

- F.J. Gathorne-Hardy, W.E.H. Harcourt-Smith

- The super-eruption of Toba, did it cause a human bottleneck?

○ Journal of Human Evolution, 45 (2003), pp. 227-230

9.

○ Haslam et al., 2010 
M. Haslam, C. Clarkson, M. Petraglia, R. Korisettar, S. Jones, C. Shipton, P. Ditchfield, S.H. Ambrose

- The 74 ka Toba super-eruption and southern Indian hominins: archaeology, lithic technology and environments at Jwalapuram Locality 3

- Journal of Archaeological Science, 37 (2010), pp. 3370-3384

10.

- Hayes et al., 2002

- S.K. Hayes, D.R. Montgomery, C.G. Newhall

- Fluvial sediment transport and deposition following the 1991 eruption of Mount Pinatubo

- Geomorphology, 45 (2002), p. 211

11.

○ Jones, 2007

- S.C. Jones

- The Toba supervolcanic eruption: tephra-fall deposits in India and palaeanthropological implications

- M.D. Petraglia, B. Allchin (Eds.), The Evolution and History of Human Populations in South Asia, Springer (2007), pp. 173-200

12.

○ Jones, 2010

- S.C. Jones

- Palaeoenvironmental response to the $\sim 74 \mathrm{ka} \mathrm{Toba}$ ash-fall in the Jurreru and Middle Son Valleys in southern and north-central India

- Quaternary Research, 73 (2010), pp. 336-350

13.

- Jones and Pal, 2005

- S.C. Jones, J.N. Pal

- The middle Son Valley and the Toba supervolcanic eruption of 74 kyr BP: youngest Toba Tuff deposits and Palaeolithic associations

- Journal of Interdisciplinary Studies in History and Archaeology, 2 (2005), pp. $47-62$

14.

- Jones and Pal, 2009

- S.C. Jones, J.N. Pal

- The Palaeolithic of the middle Son Valley, north-central India: changes in hominin lithic technology and behaviour during the upper Pleistocene

- Journal of Anthropological Archaeology, 28 (2009), p. 323

15.

- Kataoka et al., 2009

- K.S. Kataoka, V. Manville, T. Nakajo, A. Urabe

- Impacts of explosive volcanism on distal alluvial sedimentation: examples from the Pliocene-Holocene volcaniclastic successions of Japan

- Sedimentary Geology, 220 (2009), p. 306

16.

- Manville et al., 2005

- V. Manville, E.H. Newton, J.D.L. White

- Fluvial responses to volcanism: resedimentation of the 1800a Taupo ignimbrite eruption in the Rangitaiki River catchment, north Island, New Zealand

- Geomorphology, 65 (2005), pp. 49-70

17.

○ Miall, 1996 
- A.D. Miall

- The Geology of Fluvial Deposits. Sedimentary Facies, Basin Analysis, and Petroleum Geology

- Springer-Verlag, Berlin, Heidelberg, New York, London, Paris, Tokyo, Hong Kong (1996)

18.

- Morad et al., 1991

- S. Morad, A. Bhattacharyya, I.S. Al-Aasm, K. Ramseyer

- Diagenesis of quartz in the Upper Proterozoic Kaimur sandstones, Son Valley, central India

○ Sedimentary Geology, 73 (1991), p. 209

19.

- Nanson and Croke, 1992

- G.C. Nanson, J.C. Croke

- A genetic classification of floodplains

○ Geomorphology, 4 (1992), pp. 459-486

20.

○ Ninkovich, 1979

- D. Ninkovich

- Distribution, age and chemical composition of tephra layers in deep-sea sediments off western Indonesia

- Journal of Volcanology and Geothermal Research, 5 (1979), pp. 67-86

21.

- Ninkovich et al., 1978b

- D. Ninkovich, R. Sparks, M. Ledbetter

- The exceptional magnitude and intensity of the Toba eruption, Sumatra: an example of the use of deep-sea tephra layers as a geological tool

- Bulletin of Volcanology, 41 (1978), pp. 286-298

22.

- Ninkovich et al., 1978a

- D. Ninkovich, N.J. Shackleton, A.A. Abdel-Monem, J.D. Obradovich, G. Izett

- K-Ar age of the late Pleistocene eruption of Toba, north Sumatra

- Nature, 276 (1978), pp. 574-577

23.

- Oppenheimer, 2002

- C. Oppenheimer

- Limited global change due to the largest known Quaternary eruption, Toba $\sim 74 \mathrm{kyr}$ BP?

○ Quaternary Science Reviews, 21 (2002), pp. 1593-1609

24.

- Pattan et al., 1999

- J.N. Pattan, P. Shane, V.K. Banakar

- New occurrence of Youngest Toba Tuff in abyssal sediments of the central Indian basin

○ Marine Geology, 155 (1999), pp. 243-248

25.

- Rampino and Self, 1992

- M.R. Rampino, S. Self

- Volcanic winter and accelerated glaciation following the Toba super-eruption

- Nature, 359 (1992), p. 50 
26.

- Rose and Chesner, 1990

- W.I. Rose, C.A. Chesner

- Worldwide dispersal of ash and gases from earth's largest known eruption:

Toba, Sumatra, 75 ka. Palaeogeography, Palaeoclimatology

- Palaeoecology, 89 (1990), pp. 269-275

27.

- Sarna-Wojcicki and Davis, 1991

- A.M. Sarna-Wojcicki, J.O. Davis

- Quaternary tephrochronology

- ,in: R.B. Morrison (Ed.), The Geology of North America, Quaternary

Nonglacial Geology: Conterminous U.S, The Geological Society of America, Boulder, Colorado (1991), pp. 93-116

28.

- Schulz et al., 2002

- H. Schulz, K.-C. Emeis, H. Erlenkeuser, U. von Rad, C. Rolf

- The Toba volcanic event and interstadial/stadial climates at the marine isotopic stage 5 to 4 transition in the northern Indian Ocean

- Quaternary Research, 57 (2002), pp. 22-31

29.

- Sharma and Clark, 1982

- G.R. Sharma, J.D. Clark

- Palaeoenvironments and Prehistory in the Middle Son Valley, Madhya

Predesh, North Central India

- (1982) Allahabad, Abinash Prakashan

30.

- Singh, 1980

- I.B. Singh

- Precambrian sedimentary sequences of India: their peculiarities and comparison with modern sediments

- Precambrian Research, 12 (1980), p. 411

31.

- Song et al., 2000

- S.R. Song, C.H. Chen, M.Y. Lee, T.F. Yang, Y. lizuka, K.Y. Wei

- Newly discovered eastern dispersal of the youngest Toba Tuff

- Marine Geology, 167 (2000), p. 303

32.

○ Westgate et al., 1998

- J.A. Westgate, P.A.R. Shane, N.J.G. Pearce, W.T. Perkins, R. Korisettar, C.A. Chesner, M.A.J. Williams, S.K. Acharyya

- All Toba tephra occurrences across peninsular India belong to the 75,000 $\mathrm{yr}$ B.P. eruption

○ Quaternary Research, 50 (1998), pp. 107-112

33.

- Williams, in press

- Williams, M., in press. Did the 73 ka Toba super-eruption have an enduring effect? insights from genetics, prehistoric archaeology, pollen analysis, stable isotope geochemistry, geomorphology, ice cores, and climate models. Quaternary International. doi:10.1016/j.quaint.2011.03.045. 
34.

- Williams and Royce, 1982

- M.A.J. Williams, K. Royce

- Quaternary geology of the middle Son Valley, North Central India: implications for prehistoric archaeology

- Palaeogeography, Palaeoclimatology, Palaeoecology, 38 (1982), p. 139

O

35.

- Williams and Royce, 1983

- M.A.J. Williams, K. Royce

- Alluvial history of the middle Son Valley, north central India

- G.R. Sharma, J.D. Clark (Eds.), Paleo-environments and Prehistory in the Middle Son Valley, Madhya Pradesh, North Central India, A.H. Wheeler and co. (1983)

36.

- Williams and Clarke, 1995

- M.A.J. Williams, M.F. Clarke

- Quaternary geology and prehistoric environments in the Son and Belan Valleys, north central India

- S. Wadia, R. Korisettar, V.S. Kale (Eds.), Quaternary Environments and Geoarcheology of India, Geological Society of India, Bangalore (1995), pp. 282-308

37.

○ Williams et al., 2006

- M.A.J. Williams, J.N. Pal, M. Jaiswal, A.K. Singhvi

- River response to Quaternary climatic fluctuations: evidence from the Son and Belan Valleys, north-central India

- Quaternary Science Reviews, 25 (2006), pp. 2619-2631

38.

- Williams et al., 2009

- M.A.J. Williams, S.H. Ambrose, S. van der Kaars, C. Ruehlemann, U. Chattopadhyaya, J. Pal, P.R. Chauhan

- Environmental impact of the $73 \mathrm{ka}$ Toba super-eruption in South Asia

- Palaeogeography, Palaeoclimatology, Palaeoecology, 284 (2009), pp. 295-314 39.

- Zielinski et al., 1996

- G.A. Zielinski, P.A. Mayewski, L.D. Meeker, S. Whitlow, M.S. Twickler

- A 110,000-Yr record of explosive volcanism from the GISP2 (Greenland) ice core

○ Quaternary Research, 45 (1996), pp. 109-118 


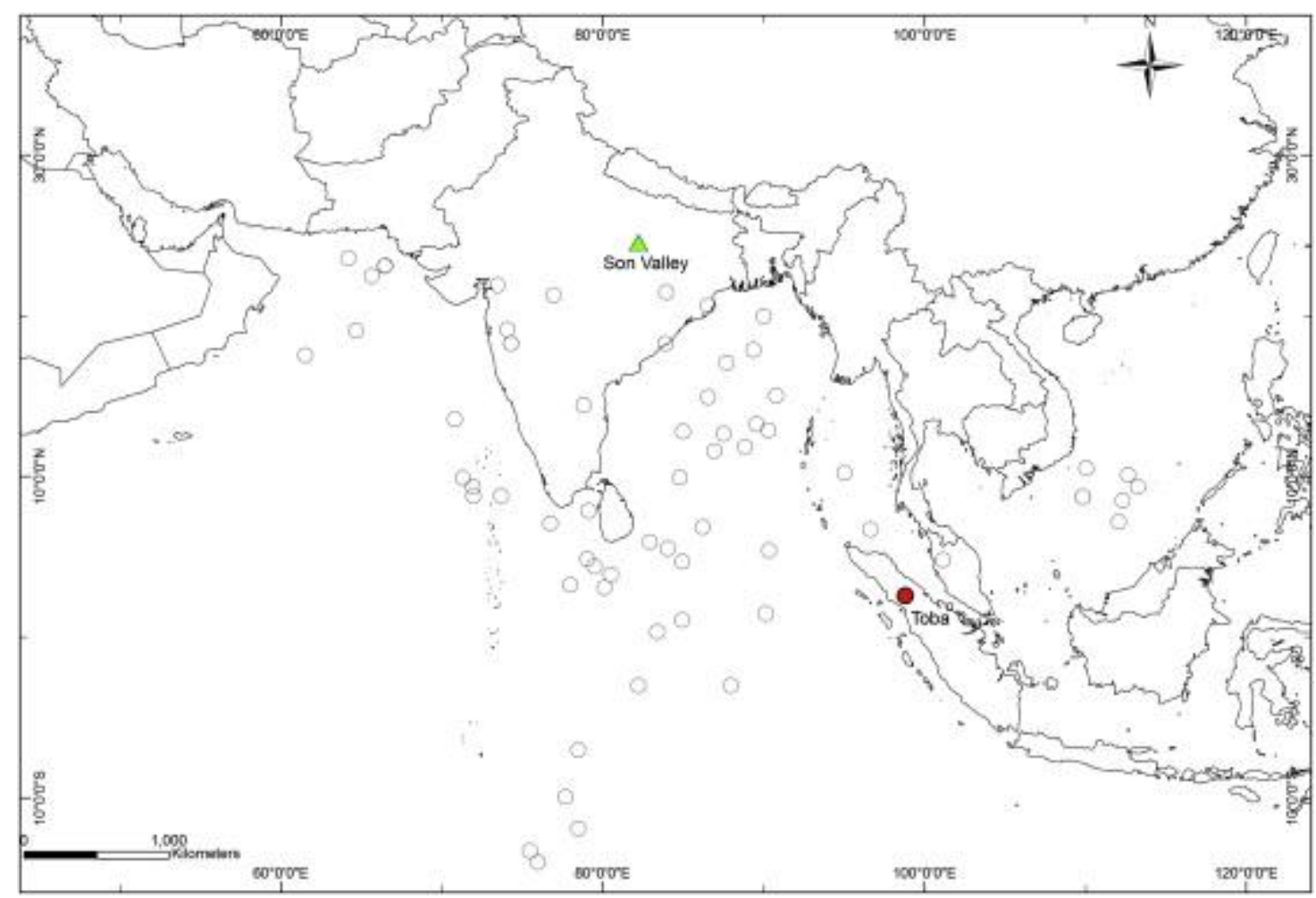

Fig. 1. Map showing the distribution of terrestrial and marine sites in which the YTT ash-fall has been identified. YTT deposits have been found in deep-sea sediments from the Indian Ocean, Bay of Bengal, Central Indian Ocean Basin, Arabian Sea and South China Sea; terrestrial sites are found in India, Bangladesh and Malaysia (data from [Oppenheimer, 2002], [Ninkovich et al., 1978a], [Ninkovich et al., 1978b], [Acharyya and Basu, 1993], [Pattan et al., 1999], [Song et al., 2000] and [Gasparotto et al., 2000]). Red dot indicates the location of Toba; green dot indicates the Son Valley. 


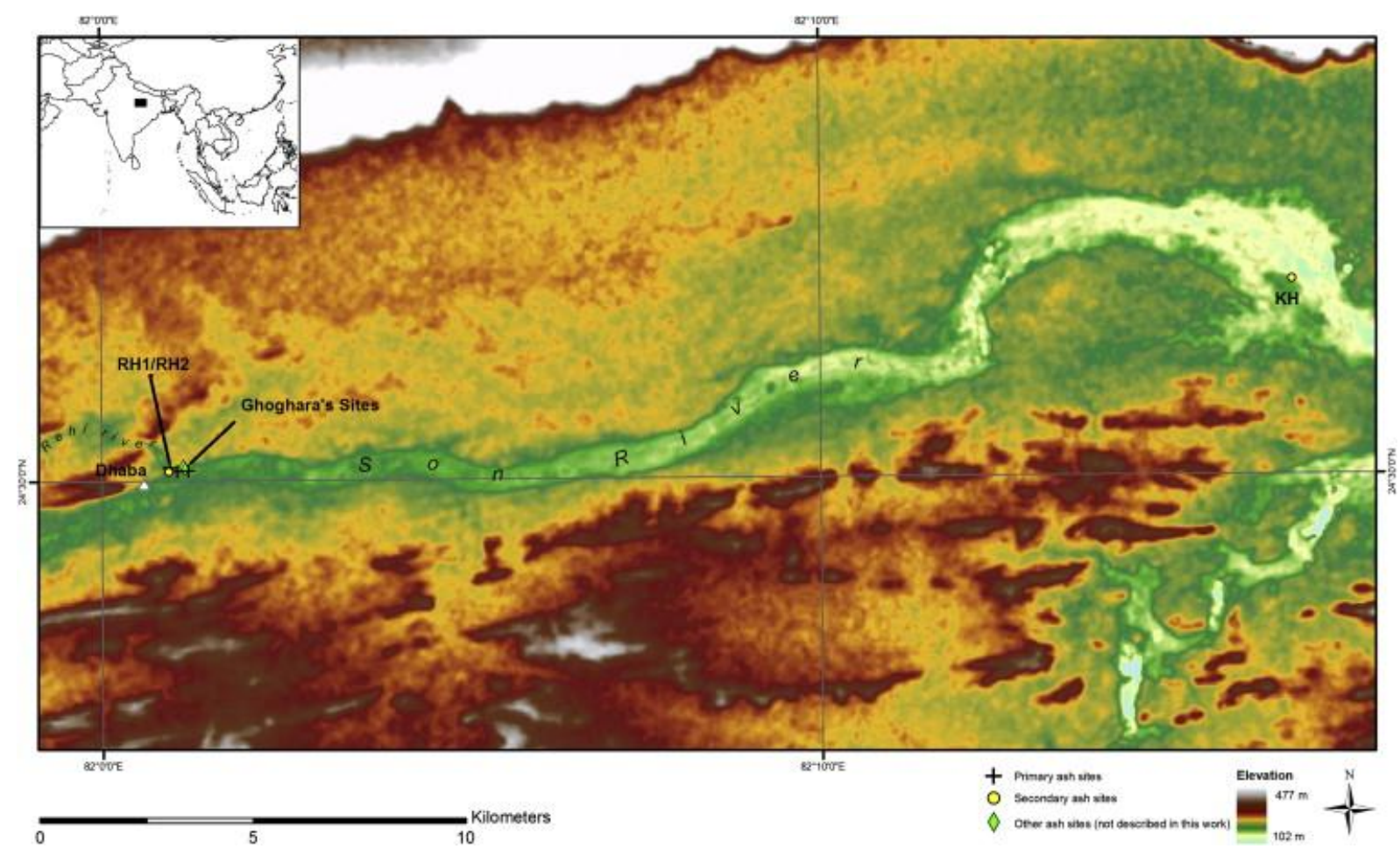

Fig. 2. Location of the tephra sites in the Son valley. Red and yellow dots on the map represent the logged sites presented in this work. DEM from ASTER GDEM (ASTER GDEM is a product of METI and NASA) 


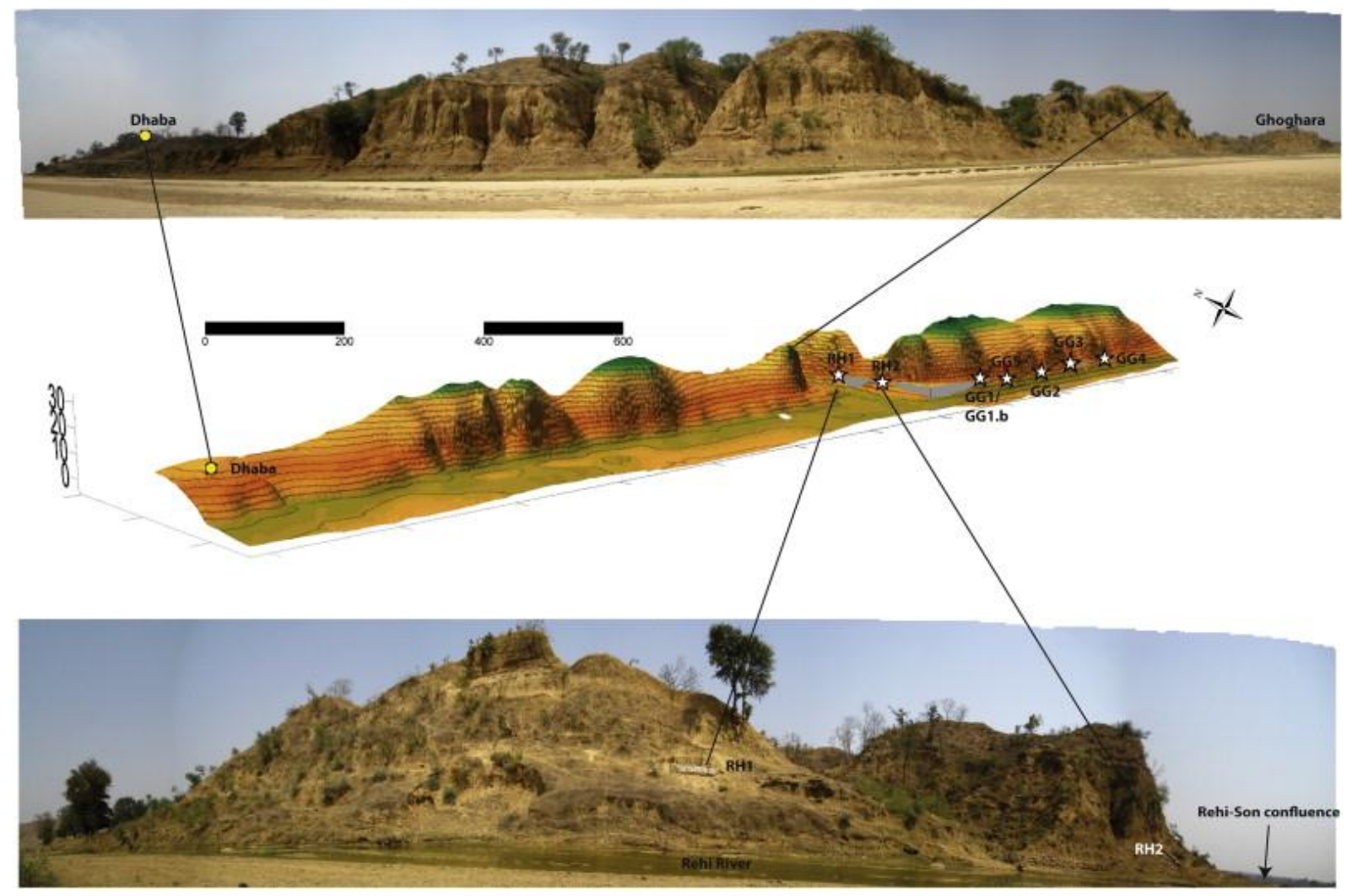

Fig. 3. Sites and position of YTT ash in the Ghoghara-Rehi cliffs. The topographic profile was derived from a survey carried out with a Zeiss Elta R55 EDM total station. The photomosaics show the morphology of the riverside cliffs and the position of the ash site RH1. 
Table 1. List of the sites investigated during the 2009 field campaign. Sites evidenced in grey are the type-sections used to determine the facies and represented in the logs in Fig. 7.

\begin{tabular}{|c|c|c|c|c|c|c|c|c|}
\hline \multirow[t]{4}{*}{ Type } & Site & $\begin{array}{c}\text { Localit } \\
\mathbf{y}\end{array}$ & Coord & dinates & $\begin{array}{c}\text { Previo } \\
\text { usly } \\
\text { describ } \\
\text { ed }\end{array}$ & $\begin{array}{c}\text { Thickn } \\
\text { ess of } \\
\text { the } \\
\text { primar } \\
\text { y ash } \\
\text { (cm) }\end{array}$ & $\begin{array}{l}\text { Thickn } \\
\text { ess of } \\
\text { the } \\
\text { second } \\
\text { ary } \\
\text { ash } \\
\text { (m) }\end{array}$ & $\begin{array}{c}\text { Selection } \\
\text { criteria }\end{array}$ \\
\hline & RH1 & Rehi & $\begin{array}{l}24^{\circ} 30^{\prime} 9^{\prime \prime} \\
\mathrm{N}\end{array}$ & $\begin{array}{l}82^{\circ} 0^{\prime} \\
56^{\prime \prime} \mathrm{E}\end{array}$ & NO & 5 & 1.6 & Western site \\
\hline & $\begin{array}{l}\text { GG } \\
1\end{array}$ & $\begin{array}{l}\text { Ghogar } \\
\text { a cliffs } \\
\text { (Main } \\
\text { Site) }\end{array}$ & $\begin{array}{l}24^{\circ} 30^{\prime} 7^{\prime \prime} \\
\mathrm{N}\end{array}$ & $\begin{array}{l}82^{\circ} 1^{\prime} \\
2^{\prime \prime} \mathrm{E}\end{array}$ & $\frac{\frac{\text { Willia }}{\text { ms and }}}{\underline{\text { Royce, }}}$ & 5 & 1.5 & $\begin{array}{l}\text { Main ash } \\
\text { site, firstly } \\
\text { discovered }\end{array}$ \\
\hline & $\begin{array}{l}\text { GG } \\
1 . b\end{array}$ & $\begin{array}{l}\text { Ghogar } \\
\text { a cliffs } \\
\text { (gully) }\end{array}$ & $\begin{array}{l}24^{\circ} 30^{\prime} 7 \\
5^{\prime \prime} \mathrm{N}\end{array}$ & $\begin{array}{l}82^{\circ} 1^{\prime} 2.9 \\
9^{\prime \prime} \mathrm{E}\end{array}$ & NO & $2-5$ & 1.05 & $\begin{array}{l}\text { Sedimentol } \\
\text { ogical } \\
\text { structures }\end{array}$ \\
\hline \multirow[t]{5}{*}{$\begin{array}{l}\text { Primary + Sec } \\
\text { ondary ASH }\end{array}$} & $\begin{array}{l}\text { GG } \\
2\end{array}$ & $\begin{array}{l}\text { Ghogar } \\
\text { a cliffs }\end{array}$ & $\begin{array}{l}24^{\circ} 30^{\prime} 1 \\
0^{\prime \prime} \mathrm{N}\end{array}$ & $\begin{array}{l}82^{\circ} 1^{\prime} \\
8^{\prime \prime} \mathrm{E}\end{array}$ & NO & $\begin{array}{l}0.1 \\
\text { (disturb } \\
\text { ed } \\
\text { lenses } \\
\text { only) }\end{array}$ & 0.90 & I \\
\hline & $\begin{array}{l}\text { GG } \\
3\end{array}$ & $\begin{array}{l}\text { Ghogar } \\
\text { a cliffs }\end{array}$ & $\begin{array}{l}24^{\circ} 30^{\prime} 8^{\prime \prime} \\
\mathrm{N}\end{array}$ & $\begin{array}{l}82^{\circ} 1^{\prime} \\
9^{\prime \prime} \mathrm{E}\end{array}$ & NO & $\begin{array}{l}0.45 \\
\text { (disturb } \\
\text { ed) }\end{array}$ & 1.4 & / \\
\hline & $\begin{array}{l}\text { GG } \\
4\end{array}$ & $\begin{array}{l}\text { Ghogar } \\
\text { a cliffs }\end{array}$ & $\begin{array}{l}24^{\circ} 30^{\prime} 7^{\prime \prime} \\
\mathrm{N}\end{array}$ & $\begin{array}{l}82^{\circ} 1^{\prime} \\
11^{\prime \prime} \mathrm{E}\end{array}$ & NO & $0.1-0.4$ & 2.28 & Eastern site \\
\hline & $\begin{array}{l}\text { GG } \\
5\end{array}$ & $\begin{array}{l}\text { Ghogar } \\
\text { a cliffs }\end{array}$ & $\begin{array}{l}24^{\circ} 30^{\prime} 1 \\
4^{\prime \prime} \mathrm{N}\end{array}$ & $\begin{array}{l}82^{\circ} 1^{\prime} 20 . \\
6^{\prime} \mathrm{E}\end{array}$ & NO & $\begin{array}{l}\text { disturb } \\
\text { ed } \\
\text { lenses } \\
\text { only }\end{array}$ & $\sim 1$ & / \\
\hline & RH2 & $\begin{array}{l}\text { Rehi } \\
\text { conflue } \\
\text { nce }\end{array}$ & $\begin{array}{l}24^{\circ} 30^{\prime} 6 \\
" \mathrm{~N}\end{array}$ & $\begin{array}{l}82^{\circ} 0^{\prime} \\
55^{\prime \prime} \mathrm{E}\end{array}$ & NO & I & 1.3 & $\begin{array}{l}\text { Western } \\
\text { secondary } \\
\text { only site }\end{array}$ \\
\hline $\begin{array}{l}\text { Secondary } \\
\text { ASH only }\end{array}$ & $\mathrm{KH}$ & $\begin{array}{l}\text { Khunte } \\
\text { li }\end{array}$ & $\begin{array}{l}24^{\circ} 32^{\prime} 2 \\
8^{\prime \prime} \mathrm{N}\end{array}$ & $\begin{array}{l}82^{\circ} 16^{\prime} \\
33^{\prime \prime} \mathrm{E}\end{array}$ & $\begin{array}{l}\frac{\text { Achary }}{\text { ya and }} \\
\frac{\text { Basu, }}{1993}\end{array}$ & I & 2.2 & $\begin{array}{l}\text { Situated on } \\
\text { the right } \\
\text { side of the } \\
\text { river }\end{array}$ \\
\hline
\end{tabular}

